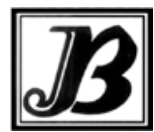

J. Bio-Sci. 27: 43-58, 2019

ISSN 1023-8654

http://www.banglajol.info/index.php/JBS/index

DOI: https://doi.org/10.3329/jbs.v27i0.44670

\title{
MICROBIOLOGICAL QUALITY ASSESSMENT OF LOCALLY VENDED AND COMMERCIALLY PACKED FRUIT JUICES IN CHITTAGONG CITY OF BANGLADESH
}

\author{
F Sultana, LW Marzan* and SA Mina \\ Department of Genetic Engineering and Biotechnology, Faculty of Biological Sciences, University of \\ Chittagong, Chittagong- 4331, Bangladesh
}

\begin{abstract}
Microbiological investigation has been undertaken for freshly prepared and commercially packed fruit juices of Chittagong city, Bangladesh. Physicochemical analysis as $\mathrm{pH}$, sugar content, total soluble solid (TSS), total dissolved solid (TDS), acidity, moisture content and microbiological parameters i.e. total viable count (TVC), total coliform count (TCC), fecal coliform count (FCC), total staphylococcal count (TSC), Vibrio spp., Salmonella spp., Shigella spp. were examined for all samples. No microorganisms were found positive in packed fruit juice samples, whereas the range of TVC, TCC, and TSC were found to be $2.0 \times 10^{3}-1.0 \times 10^{5}, 0.15 \times 10^{2}-11 \times 10^{2}$ and $1.0 \times 10^{2}-2.0 \times 10^{4} \mathrm{cfu} / \mathrm{ml}$ respectively, though there was no detectable FCC and Salmonella, Shigella for vended samples. Human pathogenic Vibrio cholerae, Klebsiella pneumoniae and Staphylococcus aureus were identified by biochemical tests and further confirmed by $16 \mathrm{~S}$ rDNA sequence analysis. Antibiotic sensitivity of Klebsiella pneumoniae and Staphylococcus aureus were found against ciprofloxacin, imipenem, gentamicin, levofloxacin except amoxicillin; whereas Vibrio cholerae showed resistant to all above antibiotics. Hence, proper awareness and regular monitoring are required during vended fruit juice handling as antibiotic resistant pathogenic bacteria can easily spread through the contaminated fruit juices to the consumers.
\end{abstract}

Key words: Antibiotic resistance, Fruit juice, Microbial contamination, Klebsiella pneumoniae, Staphylococcus aureus, Vibrio cholerae

\section{Introduction}

Fruit juices are common beverages in many countries and now becoming an important part of modern diet because of its excellent taste, nutritious value and health benefits (Tasnim et al. 2010). In tropical countries like Bangladesh, there is a high demand for consumption of both packed and vended fruit juices in summer to all income as well as age groups of people. Fruit juices are fat-free, rich in minerals and vitamin $\mathrm{C}$, polyphenolics, flavonoids, carotenoids, tocopherols also a good source of antioxidant phytochemicals which can decrease the chances of cardiovascular diseases, arteriosclerosis and some other form of cancer (Wagi and Ahmed 2016).

A freshly squeezed fruit juice's appealing look and attractive taste makes it nutritious and popular but the risk due to its consumption is very important (Uddin et al. 2017). Besides, packed fruit juices are available most of the outlets in our country, contain hologram symbol and ingredients like fruit extract, water, permitted preservatives, antioxidants, citric acid which also certified by BSTI and usually stored in at room temperature. In Bangladesh, low income people preferred local and freshly prepared fruit juices for their 'fresh flavor' attributes, low cost, ready availability (Khan et al. 2015) compare to packed fruit juices even though they have properly processed and preserved.

*Author for correspondence: marzan.geb@cu.ac.bd 
Fruit juices sometimes can be responsible for human illness, if those are not kept in cold storage, it may contaminate with yeast cells or other microorganisms (Thirumala et al. 2013). Environmental or raw material contaminations occurred either during fruits is growing in fields, orchards or greenhouse; or during harvesting, post-harvest handling and distribution (Chukwuemeka and Chukwuebuka 2017). Use of contaminated water for dilution of fruit juices, dressing with unhygienic ice, prolonged preservation without taking proper protocol during refrigeration, airborne dust, smoke, insects, hands of the sellers and during transportation (Reddy et al. 2009), are great source for the proliferation of different pathogenic bacteria including Escherichia coli, Salmonella spp., Shigella spp., Staphylococcus aureus (Sandeep et al. 2001). There are several factors ( $\mathrm{pH}$, storage temperature, concentration of preservatives, etc.) have great impact on the growth of microorganisms in juices (FDA 2001). Some pathogenic organisms also can enter fruits and vegetables through damage surfaces, such as punctures, wounds, cuts and splits that occur during growing or harvesting (Durgesh et al. 2008). Contamination from raw materials and equipment, additional processing conditions, improper handling, prevalence of unhygienic conditions contribute substantially to the entry of bacterial pathogens in juices prepared from fruits or vegetables (Victorian Government Department of Human services 2005, Durgesh et al. 2008). Besides, mostly producers and consumers are not conscious about the safety, quality and hygiene of these drinks, which can be a potential factor for food borne diseases. Then, it is urgently needed to assess the bacteriological load in freshly squeezed and commercially packed fruit juices as well as their safety for human consumption in terms of bacterial pathogens (Khan et al. 2015).

Antibiotic resistance of bacteria to commonly used antibiotics, isolated from foodstuffs has a great medical significance (Khan and Malik 2001), and directly linked with disease management (Amit 2008) which is now becoming a great concern globally (Levy and Marshal 2004); therefore understanding about resistance in bacterial species is needed to take proper actions (Caprioli et al. 2000). Several reports showed that multiple antibiotic resistant (MAR) bacteria, isolated from unpasteurized fruit juices, milk, vegetables etc. can be transferred to human through consumption of those foods and cause several infections (urinary tract infections, skin infections) as well as food borne diseases as cholera, typhoid, diarrhea which can be turn into epidemic form (Jain and Yadav 2015).

So, quality control and awareness is urgently needed during whole fruit juice processing in Bangladesh. In view of the threat posed by the bacterial pathogens in fruit juices, the present study aims to investigate the microbial assessment of local vended (freshly prepared) and commercially packed fruit juices, where objectives include-isolation and enumeration of bacteria from fruit juice samples, their characterization and identification by established biochemical and molecular techniques and finally determination of antibiotic sensitivity in order to create public awareness about fruit juice handling (processing, consumption, preservation and transportation) to ensure food safety related to human health.

\section{Materials and Methods}

\section{Sampling area and collection of samples}

Packed fruit juice samples were collected based on popularity (most demanded) and only samples within the expiry date as stipulated on the labels by manufacturers were analyzed. 10 (ten) different packed popular fruit juices marketed in retail shops of Chittagong city, Bangladesh were taken for the study $\left(\mathrm{PP}_{1}, \mathrm{SP}_{2}, \mathrm{ShP}_{3}\right.$, $\left.\mathrm{DP}_{4}, \mathrm{FP}_{5}, \mathrm{OP}_{1}, \mathrm{OP}_{2}, A \mathrm{P}_{1}, \mathrm{LP}_{1}, \mathrm{LP}_{2}\right)$. Information on the labels was recorded including manufacturers address, brand name, expiry date, types of preservative(s), and compositions. Besides, a total of 30 vended (prepared freshly at roadsides) samples, were obtained from 05 (five) different vendors from six different locations in Chittagong city (Table 1) which collected in intact condition into sterile containers and systematically labeled. After collection, all samples $(n=40)$ were brought immediately into the laboratory by 
maintaining cold chain and then preserved them at $4^{\circ} \mathrm{C}$ before commencement of analysis and during experiments.

Table 1. Sampling sites of fruit juices

\begin{tabular}{|c|c|c|c|c|}
\hline Sl. No. & $\begin{array}{l}\text { Kinds of } \\
\text { sample }\end{array}$ & Sample ID & $\begin{array}{l}\text { Types } \\
\text { of } \\
\text { samples }\end{array}$ & Sampling sites \\
\hline $\begin{array}{l}1 . \\
2 . \\
3 . \\
4 . \\
5 . \\
6 .\end{array}$ & 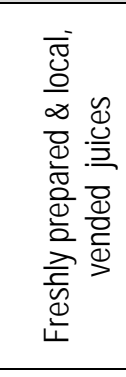 & $\begin{array}{l}S V_{1}-S V_{5} \\
O V_{1}-O V_{5} \\
P V_{1}-P V_{5} \\
M V_{1}-\mathrm{MV}_{5} \\
L V_{1}-\mathrm{LV}_{5} \\
A V_{1}-\mathrm{AV}_{5}\end{array}$ & $\begin{array}{c}\text { Sugarcane } \\
\text { Orange } \\
\text { Papaya } \\
\text { Mango } \\
\text { Lemon } \\
\text { Apple }\end{array}$ & $\begin{array}{l}\text { Zero point-University of Chittagong, Biponi Bitan } \\
\text { (New Market), } \\
\text { GEC circle, } \\
\text { Muradpur, } \\
\text { Chittagong Railway Station, } \\
\text { In front of Bati Ghar, Jamal Khan Road }\end{array}$ \\
\hline $\begin{array}{c}7 . \\
8 . \\
9 . \\
10 . \\
11 . \\
12 . \\
13 . \\
14 . \\
15 . \\
16 .\end{array}$ & 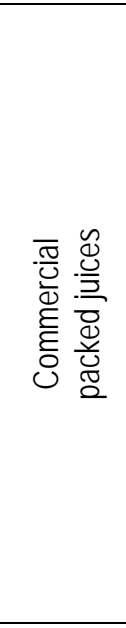 & $\begin{array}{l}\mathrm{PP}_{1} \\
\mathrm{SP}_{2} \\
\mathrm{ShP}_{3} \\
\mathrm{DP}_{4} \\
\mathrm{FP}_{5} \\
\mathrm{OP}_{1} \\
\mathrm{OP}_{2} \\
\mathrm{AP}_{1} \\
\mathrm{LP}_{1} \\
\mathrm{LP}_{2}\end{array}$ & Orange & $\begin{array}{l}\text { Products of different manufacturing companies } \\
\text { within expiry date from retail shops of different } \\
\text { areas in Chittagong city }\end{array}$ \\
\hline
\end{tabular}

\section{Physicochemical analysis}

The $\mathrm{pH}$ value was examined by using $5.0 \mathrm{ml}$ of each juice sample in a digital $\mathrm{pH}$ meter at $20^{\circ} \mathrm{C}$ (HANNA, Italy) (Oluwole et al. 2016). Estimation of sugar content was done according to Nelson-Somogyi method (Nelson 1944, Somogyi 1952), where optical density (OD) was measured (at $\lambda=500 \mathrm{~nm}$ ) using UV spectrophotometer (Shimadzu, Japan).

Total soluble solids (TSS) and total dissolved solids (TDS) were determined according to Ranganna (1986). Titratable acidity (TA) was determined by titrimetrically with the usual acid base titration method (Ranganna 1986) and moisture content (MC) was determined by oven drying method (Chukwuemeka and Chukwuebuka 2017) and calculated as follows: 


$$
\text { Percentage of MC = Weight of sample after drying } \quad \times 100
$$

All experiments were conducted at ambient temperature and carried out in three replications.

\section{Isolation and screening of bacteria from samples}

\section{Total viable count (TVC)}

Serial dilution of the samples were done $\left(10^{-1}\right.$ to $\left.10^{-7}\right)$ according to Addisu and Kiros (2016), then $0.1 \mathrm{ml}$ of each diluted sample was spread on nutrient agar (NA) plate and incubated at $37^{\circ} \mathrm{C}$ for 24 hours. After incubation the inoculated plates were screened for the discrete colonies of bacteria and population density was measured as colony forming unit per $\mathrm{ml}$ (cfu/ml) (Rashed et al. 2013); where less than five colonies for a particular organism growing on a plate were ignored (Qiu et al. 2000). Following purification, morphologically distinct colonies were identified by observing colony characteristics as gram nature, color and shape using a binocular biological microscope (XSZ-107BN), where colonies of similar morphological features were grouped (Beironvand et al. 2017). Then isolates were selected, cultured, purified and stored in the laboratory in glycerol stock (50\%) solution for further studies.

\section{Total coliform and faecal coliform count (TCC and FCC)}

Total coliform and faecal coliform count was detected by most probable number (MPN) technique which is a sequential combination of presumptive, confirmed and completed tests by using three different media such as; lauryl tryptose broth, brilliant green lactose bile broth and eosine-methylene blue agar (EMB), respectively (Cappuccino and Sherman 2004). Both confirmed and positive tests were used to calculate the MPN of coliform in samples according to the statistical table described by Collee et al. (1996).

\section{Total Staphylococcus spp. count (TSC)}

Total Staphylococcal count was determined by spreading the purified colonies in Manitol Salt Agar selective media (Rashed et al. 2013) and the inoculated plates were incubated at $37^{\circ} \mathrm{C}$ for $24 \mathrm{~h}$. After incubation, yellow colonies were suspected as Staphylococcus aureus and the total Staphylococcal count (TSC) were estimated as cfu/ml (Rashed et al. 2013).

\section{Total Vibrio spp. count}

For the detection of Vibrio spp. Thiosulphate citrate bile salt medium (TCBS) was used (APHA 2001), where $25.0 \mathrm{ml}$ of the sample was added in $225 \mathrm{ml}$ alkaline peptone water aseptically and incubated at $37^{\circ} \mathrm{C}$ for $24 \mathrm{~h}$ for pre-enrichment. From the incubated alkaline peptone water a loop full of mixture was streaked on the surface of TCBS agar plates and incubated at $37^{\circ} \mathrm{C}$ for $24 \mathrm{~h}$; where $2-3 \mathrm{~mm}$ diameter of yellow colony was suspected as Vibrio spp.

\section{Total Salmonella and Shigella spp. count}

For the detection of Salmonella spp. and Shigella spp., selective media SSA (Salmonella Shigella Agar) was used (APHA 2001). $1.0 \mathrm{ml}$ of each sample was inoculated into $9.0 \mathrm{ml}$ of normal saline solution and incubated at $37^{\circ} \mathrm{C}$ for $24 \mathrm{~h}$. After incubation one loop full of the mixture was aseptically transferred and streaked on the SSA media and allowed to incubate it overnight. The single colony from the SSA media was transferred into sterile dextrose broth and incubated at $37^{\circ} \mathrm{C}$ for $24 \mathrm{~h}$ until the broth become cloudy. For the identification of 
Salmonella spp. two biochemical tests such as urease and TSI (triple sugar iron) were done. For the presence of Salmonella spp., the slant turned into pinkish color for urease test, while yellow color with black spot was observed for TSI test. Besides, citrate utilization test was done in Simmons citrate agar for the identification of Shigella spp. where the media turned into blue color from green (Addisu and Kiros 2016).

\section{Phenotypic and biochemical characterization of bacterial isolates}

Standard morphological and biochemical characteristics were studied for the identification of selected bacterial isolates. They were characterized by gram staining based on cultural, morphological as well as biochemical characteristics as described in the Cowan and Steel's Manual (Barrow and Feltham 1993). For the activities of oxidase, catalase, citrate utilization, indole production, methyl-red and TSI tests, isolates were biochemically analyzed (Marzan et al. 2017). Then according to Bergey's Manual of Systemic Bacteriology the isolates were provisionally identified up to species level (Clause and Berkeley 1986, Bergey et al. 1974).

\section{PCR amplification of bacterial $16 \mathrm{~S}$ rDNA}

Genomic DNA extractions of bacterial isolates were done according to the phenol-chloroform method (Sambrook et al. 1989). A partial fragment of the 16S rDNA (Hasan et al. 2017) was amplified by using polymerase chain reaction (PCR). The following primer sequences were chosen for 16S rDNA gene amplification (Fouad et al. 2002): 8F (5'-AGAGTTTGATCCTGGCTCAG-3') and 850R (5'GACTACCAGGGTATCTAAT-3'). The PCR reaction mixture included $2.0 \mu \mathrm{l}$ of template DNA, $5.0 \mu \mathrm{l}$ of PCR master mix (Thermo Scientific Dream Taq Green, 2X), $1.0 \mu \mathrm{l}$ of each primer (Reverse and Forward) and 1.0 $\mu \mathrm{I}$ of nuclease free water; in a total of $10.0 \mu \mathrm{l}$ of final volume. A negative control (PCR mixture without DNA) was included in all PCR amplifications. Amplifications were performed in a thermal cycler (Nyx Technik) with the following PCR parameters: initial denaturation at $95^{\circ} \mathrm{C}$ for $5 \mathrm{~min}$ (one cycle), 35 cycles of denaturation at $95^{\circ} \mathrm{C}$ for 40 seconds, annealing at $57^{\circ} \mathrm{C}$ for 50 seconds, elongation (35 cycles) at $72^{\circ} \mathrm{C}$ for 1 min and followed by final elongation at $72^{\circ} \mathrm{C}$ for $3 \mathrm{~min}$ (one cycle).

\section{Analysis of amplified products}

Amplified PCR products were then analyzed by electrophoresis (Micro-Bio-Tech Brand) in 1\% (w/v) agarose gel in $1 \times$ TAE buffer, stained with ethidium bromide (1\%) (Sambrook et al. 1989), and compared with marker DNA (Gene Ruler 1 kb DNA Ladder) during visualized under ultraviolet (UV) trans-illuminator (Benda company).

\section{Sequence analysis of $16 \mathrm{~S}$ rDNA PCR product}

Sequencing of the purified $16 \mathrm{~S} r$ DNA PCR product (sample $\mathrm{AV}_{5} \mathrm{M}, \mathrm{MV}_{4} \mathrm{E}, \mathrm{MV}_{4} \mathrm{~T}$ ) was done (Biogen, South Korea) and the results were analyzed with NCBI BLAST programs (https://blast.ncbi.nlm.nih.gov) which were finally submitted to GenBank by using Bankit submission tool. Phylogenetic tree was constructed from the isolated $16 \mathrm{~S} r D N A$ bacterial sequence of $\mathrm{MV}_{4} \mathrm{E}$ sample, with their mostly identical respective reference sequences from GenBank according to Saitou and Nei (1987).

\section{Antibiotic sensitivity test}

Susceptibility of three identified bacteria to different antimicrobial agents was measured by employing the modified Kirby-Bauer (Bauer et al. 1966) method. This method allows for the rapid determination of the efficiency of a drug by measuring the diameter of the zone of inhibition that results from diffusion of the agent into the medium surrounding the disc (Wayne 2009). Commercially available five antimicrobial discs [Amoxicillin (AML), Ciprofloxacin (CIP), Imipenem (IMP), Gentamicin (CN) and Levofloxacin (LEV)] (Himedia, 
India) were used in this study for the tests.

\section{Statistical analysis}

The experiments were conducted by using a complete randomized design with three replications. Data were captured into Microsoft Excel Software, version 2016, to calculate means and standard deviations.

\section{Results and Discussion}

\section{Physicochemical characteristics of fruit juices}

The results of physicochemical analysis of the samples were documented in Table 2. The pH values of packed and local vended fresh fruit juices were ranged from $3.06 \pm 0.02-4.14 \pm 0.01$ and $2.77 \pm 0.01-6.18 \pm 0.01$, respectively, which is within the standard value described by FDA (2001). Most of the bacteria grow at near neutral pH (Tasnim et al. 2010), but pH of fruit juices may increase during storage (Sivakov et al. 1990). A variation was observed in case of sugar content (\%) among all the packed mango juice samples recorded as $6.50 \pm 0.1$ $15.0 \pm 1 \%$, whereas $3.40 \pm 0.1-7.80 \pm 0.1 \%$ for vended fruit juices which are within the limit of BSTI standard of fruit juices (BSTI 2002). TSS is the main contributors of any fruit juice, where according to Bangladesh standards (BDS 513: 2013- fruits and vegetables juice -3rd revision) it should be present in fruits or vegetables juice at minimum 12\%. Almost all samples of packed and freshly prepared vended juices showed TSS within the reference range except vended apple juices, though those are slightly increased (12.19 $\pm 0.01 \%)$, compared to reference value. Increase of TSS has been reported by Mahajan (1994), which may be occurred due to storage duration.

The difference of TSS\% and sugar content (\%) for different samples may be due to additional soluble salts or artificial sweeteners. TDS were found in highest amount $(6.28 \pm 0.01 \%)$ for mango (vended) juices and lowest $(2.06 \pm 0.01 \%)$ for $\mathrm{ShP}_{3}$ (packed) mango juices. Organic acids lead nutritive value of fruit juices and confer individual originality which plays very important role in the flavor of the products (Ullah and Khan 2005). Our results showed highest acidity in $\mathrm{AP}_{1}$ (apple packed) $(2.94 \pm 0.01 \%)$ and lowest in sugarcane vended $\left(\mathrm{SV}_{1}-\mathrm{SV}_{5}\right)$ juices $(0.20 \pm 0.07 \%)$ among all packed and vended fruit juices. In case of packed fruit juice samples, highest amount of $\mathrm{MC}$ was found in orange juices $-\mathrm{OP}_{1}(89 \pm 1.0 \%)$, whereas lowest amount was in apple juices $-\mathrm{AP}_{1}(81 \pm 0.5 \%)$. Besides, highest amount of $\mathrm{MC} \%(90 \pm 0.1 \%)$ was present in freshly prepared vended apple juices $\left(A \bigvee_{1}-A \bigvee_{5}\right)$.

\section{Screening and isolation of bacteria}

It was observed that, TVC ranged from $2.0 \times 10^{3}-1.0 \times 10^{5} \mathrm{cfu} / \mathrm{ml}$ for 30 vended fruit juices, which were higher than the permitted level recommended by Gulf standard (2000); whereas negligible (<1.0 cfu/ml) in packed fruit juices. Beside this, coliform was found positive for 4 (four) types of vended samples (orange, papaya, mango and apple) as the number of total coliform count (TCC) were higher than standard value (Gulf standard, 2000). The total Staphylococcal count (TSC) of all vended fruit juices were also higher compared with the standard level, whereas all packed fruit juices were free from Staphylococcal count. Total faecal coliform count (FCC) was nil in both packed and vended juice samples (Table 3). 
Table 2. Physicochemical analysis of fruit juices

\begin{tabular}{|c|c|c|c|c|c|c|c|}
\hline $\begin{array}{l}\text { Kinds of } \\
\text { sample }\end{array}$ & Sample ID & $\mathrm{pH}$ value & $\begin{array}{l}\text { Sugar } \\
\text { content } \\
(\%)\end{array}$ & $\begin{array}{l}\text { TSS } \\
(\%)\end{array}$ & $\begin{array}{c}\text { TDS } \\
(\%)\end{array}$ & $\begin{array}{l}\text { T.A } \\
(\%)\end{array}$ & $\begin{array}{l}\text { MC } \\
(\%)\end{array}$ \\
\hline \multirow{6}{*}{ 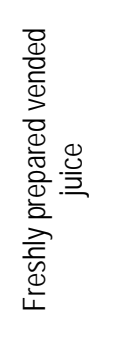 } & $\mathrm{SV}_{1}-\mathrm{SV}_{5}$ & $5.70 \pm 0.50$ & $4.60 \pm 0.1$ & $6.63 \pm 0.01$ & $2.94 \pm 0.01$ & $0.20 \pm 0.07$ & $79 \pm 0.2$ \\
\hline & $O V_{1}-O V_{5}$ & $5.33 \pm 0.01$ & $4.80 \pm 0.3$ & $6.58 \pm 0.01$ & $5.46 \pm 0.01$ & $0.30 \pm 0.01$ & $71 \pm 0.2$ \\
\hline & $P V_{1}-P V_{5}$ & $6.18 \pm 0.01$ & $5.60 \pm 0.1$ & $7.43 \pm 0.01$ & $4.78 \pm 0.05$ & $0.83 \pm 0.01$ & $83 \pm 0.1$ \\
\hline & $\mathrm{MV}_{1}-\mathrm{MV}_{5}$ & $4.29 \pm 0.02$ & $6.80 \pm 0.2$ & $9.73 \pm 0.01$ & $6.28 \pm 0.01$ & $0.64 \pm 0.01$ & $84 \pm 0.1$ \\
\hline & $\mathrm{LV}_{1} \cdot \mathrm{LV}_{5}$ & $2.77 \pm 0.01$ & $3.40 \pm 0.1$ & $1.08 \pm 0.01$ & $2.17 \pm 0.01$ & $1.60 \pm 0.05$ & $82 \pm 0.2$ \\
\hline & $A V_{1} \cdot A V_{5}$ & $3.95 \pm 0.01$ & $7.80 \pm 0.1$ & $12.19 \pm 0.01$ & $2.96 \pm 0.01$ & $0.80 \pm 0.01$ & $90 \pm 0.1$ \\
\hline \multirow{10}{*}{ 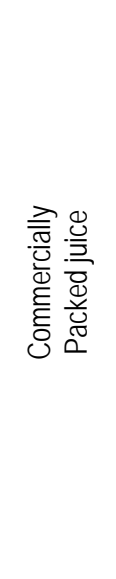 } & $\mathrm{PP}_{1}$ & $3.16 \pm 0.01$ & $10.60 \pm 0.1$ & $10.62 \pm 0.01$ & $2.19 \pm 0.01$ & $2.56 \pm 0.01$ & $88 \pm 1.0$ \\
\hline & $\mathrm{SP}_{2}$ & $3.47 \pm 0.05$ & $9.40 \pm 0.1$ & $9.23 \pm 0.01$ & $2.13 \pm 0.03$ & $2.52 \pm 0.01$ & $83 \pm 0.2$ \\
\hline & $\mathrm{ShP}_{3}$ & $3.73 \pm 0.01$ & $11.40 \pm 0.2$ & $9.75 \pm 0.01$ & $2.06 \pm 0.01$ & $2.34 \pm 0.02$ & $85 \pm 0.5$ \\
\hline & $\mathrm{DP}_{4}$ & $3.06 \pm 0.02$ & $9.60 \pm 0.1$ & $8.25 \pm 0.01$ & $2.17 \pm 0.01$ & $2.76 \pm 0.01$ & $87 \pm 1.0$ \\
\hline & $\mathrm{FP}_{5}$ & $4.14 \pm 0.01$ & $15.00 \pm 1.0$ & $9.65 \pm 0.01$ & $2.23 \pm 0.02$ & $2.32 \pm 0.01$ & $84 \pm 0.2$ \\
\hline & $\mathrm{OP}_{1}$ & $3.75 \pm 0.01$ & $14.90 \pm 0.3$ & $10.25 \pm 0.01$ & $2.20 \pm 0.01$ & $2.44 \pm 0.02$ & $89 \pm 1.0$ \\
\hline & $\mathrm{OP}_{2}$ & $3.21 \pm 0.03$ & $7.10 \pm 0.1$ & $10.34 \pm 0.01$ & $2.51 \pm 0.01$ & $2.81 \pm 0.01$ & $85 \pm 0.1$ \\
\hline & $\mathrm{AP}_{1}$ & $3.33 \pm 0.01$ & $6.50 \pm 0.1$ & $4.13 \pm 0.01$ & $2.46 \pm 0.01$ & $2.94 \pm 0.01$ & $81 \pm 0.5$ \\
\hline & $\mathrm{LP}_{1}$ & $3.50 \pm 0.01$ & $12.90 \pm 0.3$ & $10.15 \pm 0.01$ & $2.10 \pm 0.01$ & $2.14 \pm 0.02$ & $87 \pm 1.0$ \\
\hline & $\mathrm{LP}_{2}$ & $3.20 \pm 0.03$ & $6.70 \pm 0.1$ & $10.24 \pm 0.01$ & $2.31 \pm 0.01$ & $2.71 \pm 0.01$ & $85 \pm 0.1$ \\
\hline
\end{tabular}

$\mathrm{TSS}=$ total soluble solids, $\mathrm{TDS}=$ total dissolved solids, $\mathrm{TA}=$ titratable acidity, $\mathrm{MC}=$ moisture content .

In this study, there was no Salmonella spp. and Shigella spp. present in both types of fruit juices and same finding was recorded previously (Odu and Adeniji 2013, Bandaru et al. 2016). Besides, 3 (three) locally vended fruit juice samples (mango, lemon, apple) showed positive results for the presence of Vibrio spp. (Table 3). There are several reasons behind the presence of those microorganisms in especially freshly prepared vended fruit juices including improper handling and processing, use of contaminated water and ice during washing and dilution, use of dirty processing utensils like juice makers knife and trays (Khalil et al. 1994). In addition, the vendors have little knowledge of food safety which can contribute and increase bacterial load during juice preparation in an unhygienic environment contaminated with air borne dust, smoke, insects, swarming flies and left them (juices) in ambient temperature as well as for prolonged preservation without any recommended preservatives or proper refrigeration facilities (Lewis et al. 2006). 
Table 3. Microbiological analysis of fruit juices

\begin{tabular}{|c|c|c|c|c|c|c|c|}
\hline & $\begin{array}{l}\text { 으 } \\
\frac{0}{0} \\
\text { 壳 } \\
\text { ஸे }\end{array}$ & 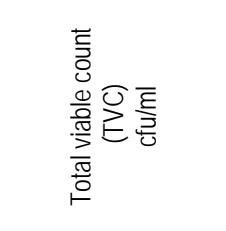 & 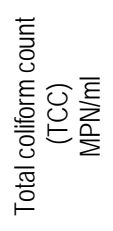 & 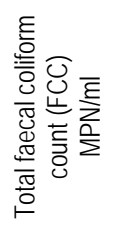 & 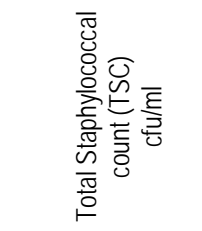 & 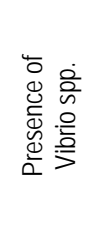 & 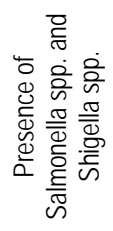 \\
\hline \multirow{6}{*}{ 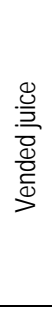 } & $S V_{1}-S V_{5}$ & $3.45 \times 10^{3}-3.55 \times 10^{3}$ & - & - & $4.5 \times 10^{2}-5.0 \times 10^{2}$ & - & - \\
\hline & $\mathrm{OV}_{1}-\mathrm{OV}_{5}$ & $0.90 \times 10^{5}-1.0 \times 10^{5}$ & $>1100$ & - & $1.5 \times 10^{3}-1.6 \times 10^{3}$ & - & - \\
\hline & $P V_{1}-P V_{5}$ & $2.55 \times 10^{4}-2.6 \times 10^{4}$ & 15 & - & $1.0 \times 10^{2}-1.5 \times 10^{2}$ & - & - \\
\hline & $M V_{1}-\mathrm{MV}_{5}$ & $7.80 \times 10^{3}-8.0 \times 10^{3}$ & $>1100$ & - & $5.5 \times 10^{3}-6.5 \times 10^{3}$ & + & - \\
\hline & $\mathrm{LV}_{5} \cdot \mathrm{LV}_{5}$ & $2.0 \times 10^{3}-2.05 \times 10^{3}$ & - & - & $2.5 \times 10^{2}-3.5 \times 10^{2}$ & + & - \\
\hline & $\mathrm{AV}_{5} \cdot \mathrm{AV}_{5}$ & $1.90 \times 10^{4}-2.0 \times 10^{4}$ & 43 & - & $1.5 \times 10^{4}-2.0 \times 10^{4}$ & + & - \\
\hline \multicolumn{2}{|c|}{$\begin{array}{l}\text { Contamination } \\
(\%)\end{array}$} & $100 \%$ & $66.6 \%$ & Nil & $100 \%$ & $50 \%$ & Nil \\
\hline \multirow{10}{*}{ 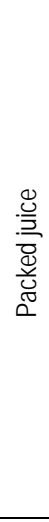 } & $\mathrm{PP}_{1}$ & - & - & - & - & - & - \\
\hline & $\mathrm{SP}_{2}$ & - & - & - & - & - & - \\
\hline & $\mathrm{ShP}_{3}$ & - & - & - & - & - & - \\
\hline & $\mathrm{DP}_{4}$ & - & - & - & - & - & - \\
\hline & $\mathrm{FP}_{5}$ & - & - & - & - & - & - \\
\hline & $\mathrm{OP}_{1}$ & - & - & - & - & - & - \\
\hline & $\mathrm{OP}_{2}$ & - & - & - & - & - & - \\
\hline & $\mathrm{AP}_{1}$ & - & - & - & - & - & - \\
\hline & $\mathrm{LP}_{1}$ & - & - & - & - & - & - \\
\hline & $\mathrm{LP}_{2}$ & - & - & - & - & - & - \\
\hline \multicolumn{2}{|c|}{$\begin{array}{c}\text { Contamination } \\
(\%)\end{array}$} & Nil & Nil & Nil & Nil & Nil & Nil \\
\hline
\end{tabular}

$(-)$ and $(+)$ indicates negative and positive result respectively.

In the current study, negligible microbial growth was found in packed fruit juices because of addition of preservatives, usage of automated machine for juice processing aseptically. Besides, those packed fruit juices are generally prepared under good sanitation practices and also preserved in appropriate storage condition. But, use of high amount of preservatives to preserve packed fruit juices can be harmful to human health (Bashar and Rahman 2007) compare to freshly prepared juices. To reduce microbial load and to prolong shelf life, pasteurization technique is used in packed fruit juices exposed to high temperature about 2 
to 5 minutes at $80^{\circ} \mathrm{C}$ which destroys all the vegetative cells except more heat resistant spores (Kisko and Roller 2005), unfortunately these processes are usually ignored by local vendors as they cannot effort it due to high cost and lack hygiene practice.

\section{Characterization and identification}

Among all the bacterial isolates from freshly prepared vended fruit juice samples, three $\left(A V_{5} M, M V_{4} E\right.$ and $\mathrm{MV}_{4} \mathrm{~T}$ ) isolates were provisionally characterized by morphological, cultural and biochemical tests and identified (Table 4) (Bergey et al. 1974, Claus and Berkeley 1986). Besides, no significant amount of bacteria was found in commercially packed fruit juices.

\section{Biochemical analysis}

Depending on gram staining, two isolates $\left(\mathrm{MV}_{4} \mathrm{E}, \mathrm{MV}_{4} \mathrm{~T}\right)$ were identified as Gram- (gram-negative) by detecting peptidoglycan which is present in a thick layer in bacteria while the other one $\left(A V_{5} M\right)$ is $\mathrm{Gram}^{+}$ (gram-positive) (Burke and Pister 1986). When bacterium contains cytochrome C oxidase, they can use oxygen for energy production with an electron transfer chain and shows oxidase positive result (Beveridge 2001). Only MV ${ }_{4}$ T was found oxidase positive during our study (Table 4). In this study, IMViC tests (Cowan and Steel's Manual 1974) were done to identify isolated bacteria where all showed catalase positive. Catalase enzyme produced by the isolates can break down hydrogen peroxide $\left(\mathrm{H}_{2} \mathrm{O}_{2}\right)$ into water and oxygen forming gas bubbles (Taylor and Achanzar 1972). All those isolates were positive for citrate utilization as they are capable to utilize citrate as a carbon source while media turn into blue from green (Koser 1924). During indole test only $\mathrm{MV}_{4} \mathrm{~T}$ were found positive as it supposed to be Vibrio cholerae having the capability to degrade amino acid (tryptophan) and produce indole (Holding and Collee 1971). Positive results were also found for them during methyl-red test where mixed acid fermentation occurred and three acids such as acetic acid, lactic acid, succinic acid were also formed in large amount decreasing the $\mathrm{pH}$ of the media visualized by methyl-red (Holding and Collee 1971). The 3 (three) isolates were then provisionally identified as Staphylococcus aureus $\left(\mathrm{AV}_{5} \mathrm{M}\right)$, Klebsiella pneumoniae $\left(\mathrm{MV}_{4} \mathrm{E}\right)$ and Vibrio cholerae $\left(\mathrm{MV}_{4} \mathrm{~T}\right)$; whereas during the confirmation test of Vibrio cholerae, positive result was found in TSI test (APHA 2001).

Pathogenic bacteria isolated from freshly prepared fruit juices may cause a serious outbreak in Bangladesh (Vojdani et al. 2008), where the presence of Vibrio cholerae in vended fruit juices may infects the intestine and increases mucous production causing diarrhea and vomiting which results in extreme dehydration may leads to death (Howard-Jones 1984). Staphylococcus aureus also an important pathogen involved in several infectious diseases including abscesses, osteomyelitis, endocarditis, and septic arthritis (Thammavongsa et al. 2015). Klebsiella pneumoniae is one of the most important members of Klebsiella genus in Enterobacteriacae family, is responsible for Pneumonia and found to cause infections in the urinary and lower biliary tract (Ryan and Ray 2004, Lopes et al. 2005). It can primarily attacks immune compromised individuals and hospitalized patients (Podschun and Ullmann 1998) and Tsukadaira et al. (2002) reported four cases of $K$. pneumoniae infection which are acute bronchopneumonia. 
Table 4. Morphological and biochemical characteristics of bacterial isolates

\begin{tabular}{|c|c|c|c|}
\hline & \multicolumn{3}{|c|}{ Bacterial isolates } \\
\hline & $\mathrm{AV}_{5} \mathrm{M}$ & $\mathrm{MV}_{4} \mathrm{E}$ & $\mathrm{MV}_{4} \mathrm{~T}$ \\
\hline \multicolumn{4}{|l|}{ Morphological characteristics } \\
\hline Gram nature & G+ & G- & G- \\
\hline \multicolumn{4}{|l|}{ Biochemical test results } \\
\hline Oxidase & - & - & + \\
\hline Catalase & + & + & + \\
\hline Citrate & + & + & + \\
\hline Indole & - & - & + \\
\hline Methyl-Red & + & + & + \\
\hline Triple sugar iron (TSI) (Slunt/butt) & - & - & $Y / Y$ \\
\hline $\begin{array}{l}\text { Provisionally identified bacteria } \\
\text { (Bergey et al. 1974, Claus and Berkeley 1986) }\end{array}$ & $\begin{array}{c}\text { Staphylococcus } \\
\text { aureus }\end{array}$ & $\begin{array}{c}\text { Klebsiella } \\
\text { pneumoniae }\end{array}$ & $\begin{array}{c}\text { Vibrio } \\
\text { cholerae }\end{array}$ \\
\hline
\end{tabular}

$(-)$ and $(+)$ indicate negative and positive result respectively; $Y=$ yellow.

\section{Molecular identification of isolated bacteria}

Biochemically identified $3\left(\mathrm{AV}_{5} \mathrm{M}, \mathrm{MV}_{4} \mathrm{E}, \mathrm{MV}_{4} \mathrm{~T}\right)$ different genus of bacteria were further confirmed by $16 \mathrm{~S}$ rDNA sequence analysis (Hasan et al. 2017). During $16 \mathrm{~S}$ rDNA PCR, all of three isolates ( $A V_{5} M, M_{4} E$ and $\mathrm{MV}_{4} \mathrm{~T}$ ) were showed positive band in the agarose gel ( $\left.800 \mathrm{bp}\right)$ (Fig. 1). Homology analysis inferred from the 16S rDNA sequence comparison clearly verified that most of the strains clustered with Staphylococcus aureus $\left(\mathrm{AV}_{5} \mathrm{M}\right)$, Klebsiella pneumoniae $\left(\mathrm{MV}_{4} \mathrm{E}\right)$ showing $97 \%$ and $94 \%$ similarity by BLAST analysis (Hasan et al. 2017). Finally all the results were submitted to GenBank and accession number MG816207 is assigned for Klebsiella pneumoniae $\left(\mathrm{MV}_{4} \mathrm{E}\right)$. Phylogenetic tree was constructed (Fig. 2) to find out similarity with the other member of Klebsiella species with the aid of molecular evolutionary genetic analysis (MEGA7) by using the neighbor-Joining method (Saitou and Nei 1987), where mostly identical sequences were taken into account. 


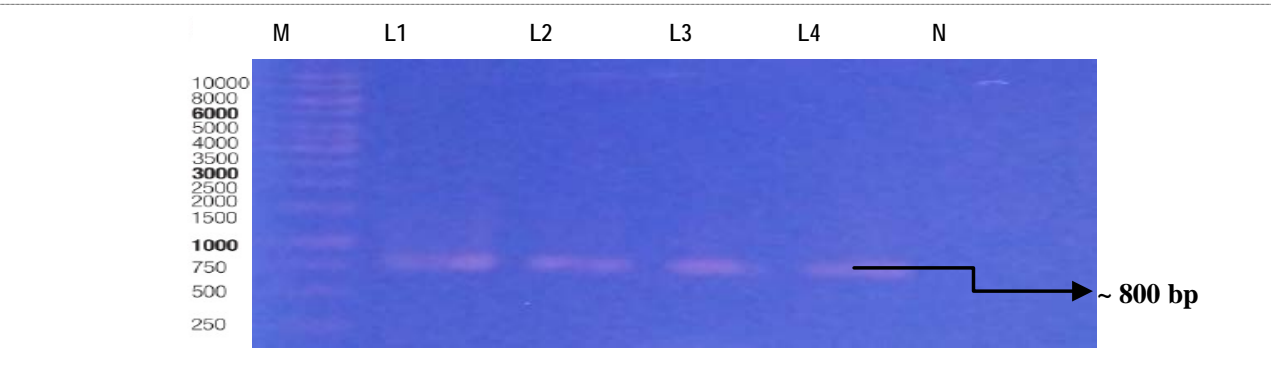

Fig. 1. Electrophoresis (1\% agarose) separation of $16 \mathrm{~S}$ rDNA gene. $\mathrm{M}$ - Marker (1 kb DNA Ladder); L1-positive control; L2-MV 4 T (Vibrio cholerae); L3-MV 4 E (Klebsiella pneumoniae); L4-AV5M (Staphylococcus aureus); N-negative control.

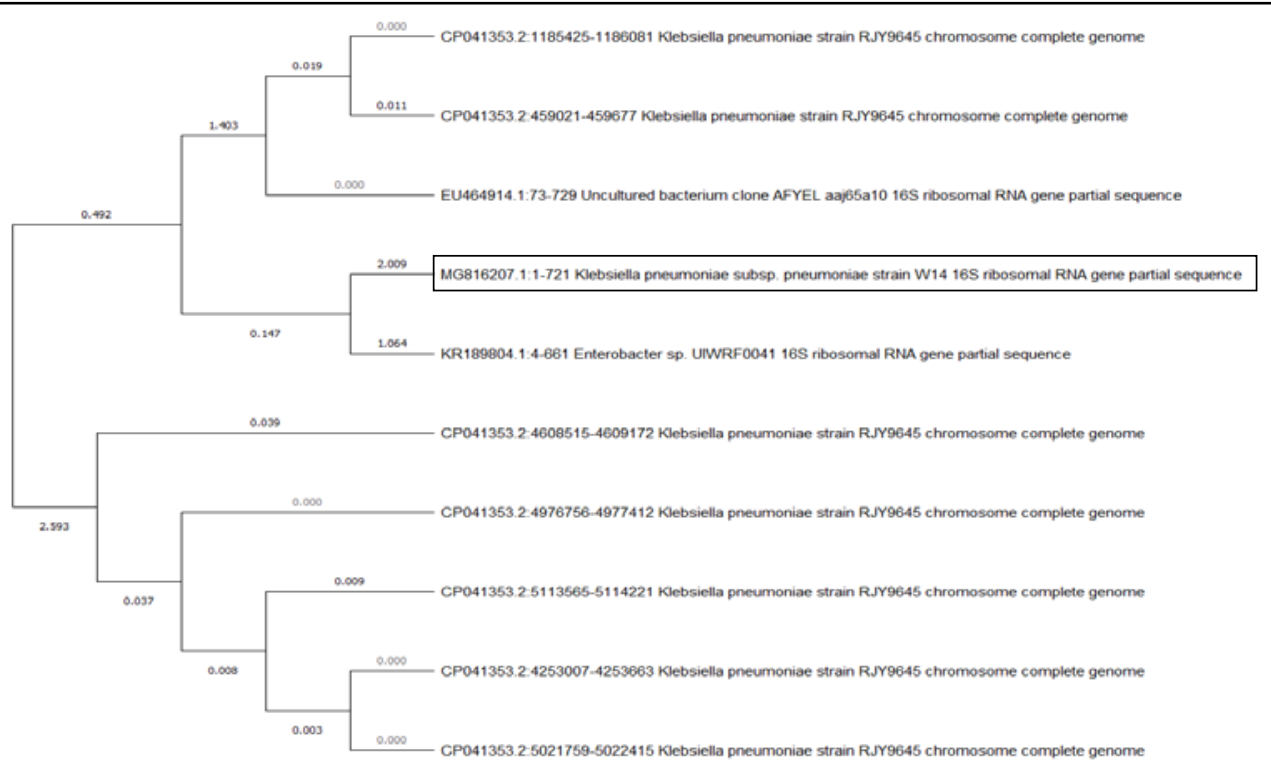

Fig. 2 Evolutionary relationships of taxa: The evolutionary history was inferred using the Neighbor-Joining method (Saitou and Nei 1987). The specific branch length between species is shown. The percentage of replicate trees in which the associated taxa clustered together in the bootstrap test (500 replicates) are shown next to the branches (Felsenstein 1985). The tree is drawn to scale, with branch lengths in the same units as those of the evolutionary distances used to infer the phylogenetic tree. The evolutionary distances were computed using the p-distance method (Nei and Kumar 2000) and are in the units of the number of base differences per site. The analysis involved 10 nucleotide sequences. Codon positions included were 
1st+2nd+3rd+Noncoding. All ambiguous positions were removed for each sequence pair. There were a total of 1473 positions in the final dataset. Evolutionary analyses were conducted in MEGA7 (Kumar et al. 2016).

\section{Antibiogram test}

Vibrio cholerae was highly resistant to all tested antibiotics used (Table 5, Fig. 3), whereas Staphylococcus aureus and Klebsiella pneumoniae were found to be resistant against Amoxicillin (AML) only. Rashed et al. (2013) found that Staphylococcus aureus and Klebsiella pneumoniae are highly resistant to amoxicillin were susceptible to imipenem (IPM), gentamicin (CN), levofloxacin (LEV) and ciprofloxacin (CIP), which is also similar with the previous report by Stock and Wiedemann (2001), Daniyan and Ajibo (2011), Srinu et al. (2012). Stock and Wiedemann (2001) reported that among the gram negative bacteria, Klebsiella pneumoniae was highly susceptible against IPM, CN, LEV. Staphylococcus aureus (AV 5 M) showed highest rate of susceptibility against to IPM, CN, LEV as described by Daniyan and Ajibo (2011), Srinu et al. (2012). Multidrug resistant bacteria (resistant to three or more antibiotics) can be a source of serious health hazards as they were found resistant to some of the most efficient and widely used antibiotics prescribed to the people as an effective treatment against major epidemics throughout the world (Prescott et al. 1999).

Table 5. Antibiotic susceptibility tests

\begin{tabular}{|c|c|c|c|c|c|}
\hline \multirow{5}{*}{$\begin{array}{l}\text { Antimicrobial } \\
\text { agents }\end{array}$} & \multirow{5}{*}{$\begin{array}{l}\text { Disc } \\
\text { code }\end{array}$} & \multirow{5}{*}{$\begin{array}{c}\text { Disc } \\
\text { potency } \\
(\mu \mathrm{g})\end{array}$} & \multicolumn{3}{|c|}{ Bacterial isolates } \\
\hline & & & $\mathrm{AV}_{5} \mathrm{M}$ & $\mathrm{MV}_{4} \mathrm{E}$ & $\mathrm{MV}_{4} \mathrm{~T}$ \\
\hline & & & Staphylococcus aureus & Klebsiella & Vibrio \\
\hline & & & & pneumoniae & cholerae \\
\hline & & & \multicolumn{3}{|c|}{ Zone ranges (mm) } \\
\hline Amoxicillin & AML & 10 & $10(R)$ & $11(\mathrm{R})$ & - \\
\hline Ciprofloxacin & CIP & 5 & $29(S)$ & $30(S)$ & - \\
\hline Imipenem & IPM & 30 & $26(S)$ & $20(S)$ & - \\
\hline Gentamicin & $\mathrm{CN}$ & 10 & $18(S)$ & $20(S)$ & - \\
\hline Levofloxacin & LEV & 5 & $30(S)$ & $30(S)$ & - \\
\hline
\end{tabular}

$\mathrm{R}=$ Resistance, $\mathrm{S}=$ Susceptible,$(-)=$ No zone of inhibition.

Ref.: Wayne P (2009)

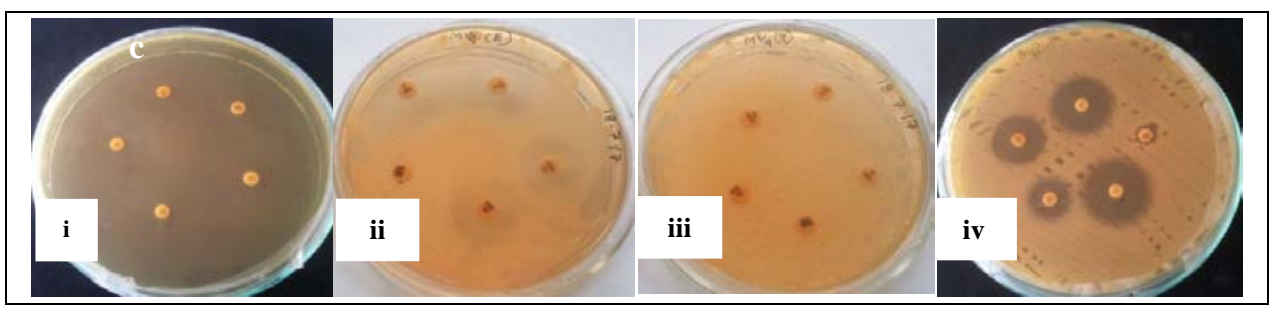


Fig. 3. Antibiotic sensitivity tests; i) Control, ii) $\mathrm{MV}_{4} \mathrm{E}$ (Klebsiella pneumoniae), iii) $\mathrm{MV}_{4} \mathrm{~T}$ (Vibrio cholerae), iv) $\mathrm{AV}_{5} \mathrm{M}$ (Staphylococcus aureus).

\section{Conclusion}

This study denotes that fruit juices of commercial brands in Bangladesh have safe microbial level according to BSTI reference value. Physicochemical properties level also safe for their consumption. Besides, 3 (three) pathogenic bacterial isolates Vibrio cholerae, Staphylococcus aureus and Klebsiella pneumoniae isolated from vended fruit juices indicates, those juices are unsafe for human consumption. The results of molecular analysis and sequencing also supported that the isolated bacteria were belonged to three different genuses as previously described. Freshly prepared vended fruit juices are not sterile and thus can favor the growth of microorganisms when conditions become favorable, which could pose health risk to their consumers. The drug resistance properties of those three bacteria can cause serious health hazards because common antibiotics may be ineffective to play action against those pathogenic bacteria. So, public awareness should be increased in this regard because exploitation of these antimicrobial agents in environment and prescribed antibiotics without clear evidence of infection would be the reason behind the emergence of such antibiotic resistant bacteria. Low price and availability make the street vended fruit juices highly popular to general people. But regular monitoring to control the quality of fruit juices for human consumption is recommended to avoid any bacterial pathogenic contamination, which will make them beneficial, nutritive and healthy drinks. Government agencies of Bangladesh must adopt measures to educate the vendors about food safety and hygienic practices and enforce adequate guidelines for juices especially freshly prepared juices. Thus, social motivation of consumers and strengthening supervision by legal authority can control adulteration and improve the quality of freshly prepared fruit juices for local people in our country.

\section{Acknowledgment}

This research was done in the Molecular Biology Laboratory of the Department of Genetic Engineering and Biotechnology, University of Chittagong and partially funded by Research and Publication office, University of Chittagong, Chittagong-4331, Bangladesh (Ref. No. 5985/2017).

\section{References}

Addisu D and Kiros $L$ (2016). Isolation and identification of bacteria from fresh fruit juices prepared in cafeterias and restaurants, Axum Town. International Journal of Integrative Sciences, Innovation and Technology, 5(2): 5-10.

American Public Health Association (APHA) (2001). Compendium of methods for the microbiological examination of foods, Washington, DC, USA. $4^{\text {th }}$ Ed.

Amit R (2008). Emergence of tetracycline-resistant Vibrio cholerae 01 serotype Inaba, in Kolkata, India. Japan Journal of Infectious Disease, 61(2): 128.

Bandaru NR, Ramakrishna N, Bharathi D and Budati S (2016). How far this road side vended fresh fruit juices are safe for consumption? Global Journal of Research Analysis, 5(6): 2277-8160.

Barrow G and Feltham RKA (1993). Cowan and steel's manual for the identification of medical bacteria. Cambridge University Press, New York, USA, 46(10): 975.

Bashar MA and Rahman SR (2007). Assessment of microbiological quality of processed fruit juice. Bangladesh Journal of Microbiology, 24(2): 166-168.

Bauer AW, Kirby WMM, Sherris JC and Tierch M (1966). Antibiotic susceptibility testing by a standardized single disk method. American Journal of Clinical Pathology, 45(4): 493-496. 
Beiranvand MM, Hashemi-Shaharaki A, Romani B, Yaghoubi S and Sadhegi P (2017). Antimicrobial activity of endophytic bacterial populations isolated from medicinal plants of Iran. Iranian Journal of Microbiology, 9(1): 11-18.

Bergey DH, Buchanan RE and Gibbons NE (1974). Bergey's manual of determinative bacteriology. Williams and Wilkins Co., Baltimore, pp. 1246.

Beveridge TJ (2001). Use of the gram stain in microbiology. Biotech Histochem, 76(3): 111-118.

BSTI (2013). Bangladesh standard specification for fruits or vegetables juice. BDS, BSTI, Dhaka, pp. 513.

Burke BE and Pister RM (1986). Cadmium transport by a $\mathrm{Cd}^{2+}$ sensitive and a $\mathrm{Cd}^{2+}$ resistant strain of Bacillus subtilis. Canadian Journal of Microbiology, 32(7): 539-542.

Cappuccino JG and Sherman N (2004). Microbiology a laboratory manual. Pearson Education, Singapore, pp. 491.

Caprioli A, Busani L, Martel JL and Helmuth R (2000). Monitoring of antibiotic resistance in bacteria of animal origin. Epidemiological and microbiological methodologies. International Journal of Antimicrobial Agents, 14(4): 259-301.

Chukwuemeka IS and Chukwuebuka IF (2017). Physicochemical and microbiological analysis of canned and bottled fruit juices sold in Owerri metropolis. World News of Natural Science, 14: 97-105.

Claus D and Berkeley RCW (1986). Genus Pseudomonus. In: Sneath, PHA, Mair NS and Sharp ME (Eds.), Bergey's Manual of Systematic Bacteriology. Williams and Wilkins, Baltimore, 2, pp.1105-1139.

Collee JG, Frasher AG, Marmion BP and Simmons A (1996). Mackie and McCartney Practical Medical Microbiology. Fourteenth edition, Churchill Living Stone.

Cowan ST (1974). Cowan and Steel's Manual for the Identification of Medical Bacteria. 2nd Edition, Cambridge University Press, Cambridge, 67-83.

Daniyan SY and Ajibo CQ (2011). Microbiological examination of sliced fruits sold in Minna metropolis. International Research Journal of Pharmacy, 2(7): 124 -129.

Durgesh PM, Ranjana GK and Varsha KV (2008). Microbiological analysis of street vended fruit juices from Neumo city, India. International Journal of Food Safety, 10: 31-34.

Felsenstein J (1985). Confidence limits on phylogenies: An approach using the bootstrap. Evolution, 39: 783-791.

Food and Drug Administration (FDA) (2001). In: Bacteriological Analytical Manual online, USA, pp.12: 1-6.

Fouad AF, Barry J, Caimano M, Clawson M, Zhu Q, Carver R, Hazlett K and Radolf JD (2002). PCR-based identification of bacteria associated with endodontic infections. Journal of Clinical Microbiology, 40(9): 3223-3231.

Gulf Standards 1016 (2000). Microbiological criteria for foodstuffs, part 1. GCC (GSO), United Arab Emirates. https://micor.agriculture.gov.au

Hasan MM, Marzan LW, Hosna A, Hakim A and Azad AK (2017). Optimization of some fermentation conditions for the production of extracellular amylases by using Chryseobacterium and Bacillus isolates from organic kitchen wastes. Journal of Genetic Engineering and Biotechnology, 15(1): 59-68.

Holding AJ and Collee JG (1971). Routine biochemical test, in method in microbiology, (Norris JR and Ribbons DW, eds), Academic Press Inc. Ltd, London, pp. 1-32.

Howard-Jones N (1984). Robert Koch and the cholera vibrio: a centenary. British Medical Journal, 288(6414): 379-381.

Jain AK and Yadav R (2015). Antibiotic resistance of different bacterial strains isolated from orange juices. American Journal of Phytomed Clinical Therapeutics, 3(1): 88-96.

Khalil K, Lindblom GB, Mazhar K and Kaijser B (1994). Flies and water as reservoirs for bacterial enteropathogens in urban and rural areas in and around Lahore Pakistan. Epidemiological Infections, 113(3): 435-444. 
Khan MM, Islam MT, Chowdhury MMH and Alim SR (2015). Assessment of microbiological quality of some drinks sold in the streets of Dhaka university campus in Bangladesh. International Journal of Food Contamination, 2(4):1-5.

Khan RMK and Malik A (2001). Antibiotic resistance and detection of $\beta$-lactamase in bacterial strains of Staphylococci and Escherichia coli isolated from foodstuffs. World Journal of Microbial Biotechnology, 17(9): 863-868.

Kisko G and Roller S (2005). Carvacrol and p-cymene inactivate Escherichia coli 0157: H7 in apple juice. BMC Microbiology, 5: 36.

Koser SA (1924). Differential tests for colon-aerogenes group in relation to sanitary quality of water. Journal of Infectious Disease, 35: 14-22.

Kumar S, Stecher G and Tamura K (2016). MEGA7: Molecular Evolutionary Genetics Analysis Version 7.0 for bigger datasets. Molecular Biology and Evolution, 33: 1870-1874.

Levy SB and Marshall B (2004). Antibacterial resistance worldwide: causes, challenges and responses. Nature Med., 10: 122-129.

Lewis JE, Thompson P, Rao BVVBN, Kalavati C and Rjanna B (2006). Human bacteria in street vended fruit juices: a case study of Visakhapatnam city, India. International Journal of Food Safety, 8: 35-38.

Lopes ACDS, Rodrigues JF and Morais MAD (2005). Molecular typing of Klebsiella pneumoniae isolates from public hospitals in Recife, Brazil. Microbiology Research, 160: 37-46.

Mahajan VVC (1994). Biochemical and enzymatic changes in apple during cold storage, Journal of Food Science Technology Mysore, 31(92): 142-144.

Marzan LW, Hossain M, Mina SA, Akter Y and Chowdhury AMMA (2017). Isolation and biochemical characterization of heavy-metal resistant bacteria from tannery effluent in Chittagong city, Bangladesh: bioremediation viewpoint. Egyptian Journal of Aquatic Research, 43(1): 65-74.

Nei M and Kumar S (2000). Molecular Evolution and Phylogenetics. Oxford University Press, New York.

Nelson N (1944). A photometric adaptation of the Somogyi method for the determination of glucose. Journal of Biological Chemical, 153: 375-380.

Odu NN and Adeniji AO (2013). Microbiological analysis of some packaged fruit juices sold in Port Hacourt metropolis, Nigeria. Nature and Science, 11(4): 30-40.

Oluwole OA, David OM, Falegan CR, Awojuyigbe B and Olajide OM (2016). Microbiological and physicochemical properties of commercial seal tampered refrigerated fruit juices. International Journal of Biological Research, 4(1): 21-24.

Podschun R and Ullmann U (1998). Klebsiella spp. as nosocomial pathogens: epidemiology, taxonomy, typing methods, and pathogenicity factors. Clinical Microbiology Review, 11(4): 589-603.

Prescott LM, Harley JP and Klein DA (1999). Microbiology, $4^{\text {th }}$ ed. New York: McGraw Hill Companies, Inc., New York, pp. 685.

Qiu X, Akdemir-Evrendilek G, Jin Z, Ruhlman KT, Zhang H and Richter ER (2000). Microbial safety and shelf-life of apple juice and cider processed by bench and pilot scale PEF systems. Innovative Food Science and Emerging Technology, 1: 77-86.

Rashed N, Aftab MU, Azizul MH, Saurab KM, Mrityunjoy A and Mujubur MR (2013). Microbiological study of vendor and packed fruit juices locally available in Dhaka city, Bangladesh. International Food Research Journal, 20(2): 10111015.

Ranganna S (1986). Handbook of analysis and quality control for fruit and vegetable products, Tata McGraw- Hill Publishing Company Ltd., New Delhi, pp.1101. 
Reddy BU, Chandrakanth N and Indu S (2009). Isolation and characterization of fecal coliforms in street vended fruit juices and its safety evaluation: a case study of Bellary city, India. International Journal of Food Safety, 11: 35-53.

Ryan KJ and Ray CG (2004). Sherris Medical Microbiology (4th Ed.), McGraw Hill.

Saitou N and Nei M (1987). The neighbor-joining method: A new method for reconstructing phylogenetic trees. Molecular Biology and Evolution, 4: 406-425.

Sambrook J, Fritsch EF and Maniatis T (1989). Molecular Cloning: A Laboratory Manual. $2^{\text {nd }}$ Ed. New York: Cold Spring Harbor Laboratory Press.

Sandeep M, Diwakar A and Abhijit G (2001). Microbiological analysis of street vended fresh squeezed carrot and kinnowmandarian juices in Patiala city, India. International Journal of Food Safety, 3: 1-13.

Sivakov L, Peterovba V, Gergiev D and Vesa N (1990). Changes in the chemical composition and transpiration of permission during storage, Godisen Zbornik Lskiot Fakuletna Univerazitot. VO Skopje, 37: 103-111.

Somogyi M (1952). Notes on sugar determination. Journal of Biological Chemistry, 195(1): 19-23.

Srinu B, Vijaya Kumar A, Kumar E and Rao TM (2012). Antimicrobial resistance of bacterial foodborne pathogens. Journal of Chemical and Pharmaceutical Research, 4(7): 3734-3736.

Stock I and Wiedemann B (2001). Natural antibiotic susceptibility of Klebsiella pneumoniae, K. oxytoca, K. planticola, K. ornithinolytica and K. terrigena strains. Journal of Medical Microbiology, 50(5): 396-406.

Tasnim F, Anwar HM, Nusrath S, Kamal HM, Lopa D and Formuzul HKM (2010). Quality assessment of industrially processed fruit juices available in Dhaka city, Bangladesh. Malaysian Journal of Nutrition, 16(3): 431-438.

Taylor WI and Achanzar D (1972). Catalase tests as an aid to the identification of enterobacteriaceae. Journal of Applied Microbiology, 24(1): 58-61.

Thammavongsa V, Kim HK, Missiakas D and Schneewind O (2015). Staphylococcal manipulation of host immune responses. Nature Review Microbiology, 13(9): 529-543.

Thirumala CN, Venumadhav N and Ugandhar T (2013). A study on microbiological status of few samples of packed fruit juices. Bioscience Discovery, 4(2): 160-164.

Tsukadaira A, Okubo Y, Kobayashi T, Wakamatsu T, Sasabayashi M and Hotta J (2002). Four cases of Klebsiella pneumonia. Nihon Kokyuki Gakkai Zasshi, 40(6): 530-535.

Uddin MK, Akter T, Parvez MAK, Nahar S, Pervin S, Debnath B and Datta S (2017). Microbial safety of street vended fruit juices in Dhaka city of Bangladesh. Journal of Advance in Microbiology, 3(2): 2456-7116.

Ullah J and Khan N (2005). Effect of optimum harvesting dates on the quality and post-harvest losses of red delicious apple stored in commercial cold store. Sarhad Journal of Agriculture, 21(1): 135-139.

Victorian Government Department of Human Services, Food Safety Unit Melbourne, Victoria. (2005). Microbiological survey of freshly squeezed juices from retail businesses across Victoria.

Vojdani JD, Beuchat LR and Tauxe RV (2008). Juice-associated outbreaks of human illness in the United States, 19952005. Journal of Food Protection, 71(2): 356-364.

Wagi S and Ahmed A (2016). A report on the quality assessment of preserved fruit juices: microbial and biochemical analysis. Science International (Lahore), 28(2): 2053-2057.

Wayne P (2009). Clinical and Laboratory Standards Institute. Performance Standard for Antimicrobial Susceptibility testing; Nineteenth Informational Supplement. CLSI document M100-S21. 
(Manuscript received on February 17, 2018 and revised on August 23, 2018) 